\title{
Antioxidant, Total Lycopene, Ascorbic Acid and Microbial Load Estimation in Powdered Tomato Varieties Sold in Dutsin-Ma Market
}

\author{
Godwin Ojochogu Adejo ${ }^{*}$, Francis Akumabi Agbali2, Orinya Sandra Otokpa ${ }^{1}$ \\ ${ }^{1}$ Department of Biochemistry \& Molecular Biology, FUDMA, Dutsin-Ma, Nigeria \\ ${ }^{2}$ Department of Food Science \& Technology, FUDMA, Dutsin-Ma, Nigeria \\ Email: ${ }^{*}$ dradejogod@gmail.com
}

Received 1 August 2015; accepted 22 August 2015; published 25 August 2015

Copyright (C) 2015 by authors and OALib.

This work is licensed under the Creative Commons Attribution International License (CC BY). http://creativecommons.org/licenses/by/4.0/

(c) (i) Open Access

\begin{abstract}
Tomato varieties sold in Dutsin-Ma market namely, UTC, Rukuta and Dan-Aka were subjected to drying in a laboratory oven, solar drier and under direct sunlight then, powdered. The antioxidant and total lycopene contents were examined and found to be unaffected by the three drying procedures, with values ranging between $68.46 \% \pm 0.90 \%$ to $80.77 \% \pm 1.11 \%$ and 123.63 to $161.98 \mathrm{mg} / \mathrm{kg}$, respectively. The ascorbic acid was also tested and values were significantly lower in all the samples subjected to sun-drying with values ranging from $17.78 \pm 1.78 \mu \mathrm{g} / \mathrm{ml}$ to $28.44 \pm 1.78 \mu \mathrm{g} / \mathrm{ml}$ as against $100.15 \pm 1.03 \mu \mathrm{g} / \mathrm{ml}$ to $164.74 \pm 2.06 \mu \mathrm{g} / \mathrm{ml}$ for oven and solar dried tomato samples $(p<0.05)$, respectively. Total microbial load, yeast/mould, and coliform counts were then investigated. They were too numerous to count (TNTC) in the sun-dried samples. Although, also found among samples that were oven and solar dried, counts of the microorganisms were within the acceptable standards of $<10^{5}$ for bacteria and $10^{3}-10^{4}$ for fungi. While solar and oven drying presented better preservation of the tomato samples, the former offers most incentive in terms of cost and quality to farmers and the people, considering its free availability and abundance in processing dry tomato powders.
\end{abstract}

\section{Keywords}

Antioxidant, Lycopene, Ascorbic, Microbial, Dutsin-Ma

Subject Areas: Biochemistry, Biotechnology

\section{Introduction}

Tomato (Lycopersiconesculentum Mill.) [1] [2], is one of the top three most important vegetables after potato,

${ }^{*}$ Corresponding author.

How to cite this paper: Adejo, G.O., Agbali, F.A. and Otokpa, O.S. (2015) Antioxidant, Total Lycopene, Ascorbic Acid and Microbial Load Estimation in Powdered Tomato Varieties Sold in Dutsin-Ma Market. Open Access Library Journal, 2: e1768. http://dx.doi.org/10.4236/oalib.1101768 
due to its wide-spread cultivation and health benefit, especially, in fighting cancer of the breast [3], prostate, cervix, stomach, rectum, as well as pharynx and oesophageal cancers [4].

Tomato is consumed all year round in various forms, being very appetizing, refreshing and pleasing to taste. Tomato fruits are eaten raw or cooked, alone or with other vegetables and food stuffs. Despite its about $94 \%$ moisture content, it remains an excellent source of minerals and vitamins. For instance, it can provide up to $40 \%$ and $15 \%$ of the daily recommended allowance of vitamins $C$ and A respectively. In addition, the red pigmentlycopene, contained in tomato is an antioxidant which helps in neutralizing the effects of damaging free radicals and thus, significantly cutting down the risk of developing various types of cancer [1] [3]-[6]. Tomatoes and its products are important contributors of lycopene, $\beta$-carotene, vitamin $\mathrm{C}$ and phenolics in food consumed by most people [7], which are all included in the list of antioxidant principles.

However, marketing of fresh tomato during the season is a great problem because of its short post-harvest life, which leads to high postharvest losses. The post-harvest losses reported for tomatoes are around $54 \%$. Short shelf-life coupled with inadequate processing facilities results in heavy revenue loss to the country. It is important to extend the shelf-life of tomato [2], therefore, development of preservation methods is beneficial to farmers who produce large quantities of tomatoes. A wide variety of tomato products are prepared using concentrated juice or pulp, which needs high cost technology for good quality products [3]. Besides, seasonal market gluts can be exploited for dehydrated products [7]. With these considerations, the development of low cost processing and packaging methodologies to produce shelf-stable and convenience products are the prime requirements of present competitive market and drying is the most suitable method to full fill the above requirements [2] [3]. However, as attractive as it may be, it is vital to ascertain that drying and pulverization of tomato does not drastically affect the quality obtainable in the fresh fruits. This is particularly with respect to the core nutrients namely, lycopene, ascorbic acid and overall antioxidant properties, and should also not add or exacerbate the microbial load in the course of its processing to powder. This work was thus, designed to study the named parameters in the various dried and pulverized tomato samples obtainable in Dutsin-Ma market, using different drying methods. The samples were handled and processed by simulating the traditional ways they are done, as closely as possible. For instance, apart from removal of adhering extraneous matters, no thorough washing or blanching was done before slicing the fresh tomatoes. In addition, the sliced fruits were placed with the inner juicy portions facing up just as it is done traditionally.

\section{Materials and Methods}

Improvised solar drier, Oven fitted with air blast, UV-Visible Spectrophotometer, Stainless steel knife, aluminium foil paper. Among other chemicals which were all of analytical grade purchased from Zayo-Sigma, Jos Plateau State and Bijo Surgicals and Chemicals, Kaduna were: 2,2-Diphenyl-picryl hydrazine (DPPH), methanol, hexane, ethanol, acetone, oxalic acid, sulphuric acid and activated charcoal. Fresh tomato samples obtained were namely; Dan-Aka, UTC and Rukuta.

\subsection{Drying}

Fresh tomato samples were obtained from the Dutsin-Ma market. They were washed with clean running water and finally rinsed twice with distilled water then, cut longitudinally into approximately four equal parts as done traditionally. One (1) kg of each of the samples in disinfected aluminum foil paper was weighed and subjected to drying under direct sunlight $\left(\approx 38^{\circ} \mathrm{C}\right)$, in an oven $\left(\right.$ at $\left.60^{\circ} \mathrm{C}\right)$ and solar drier $\left(\approx 47^{\circ} \mathrm{C}\right.$ in the drying chamber with suction). Drying was done for several days with monitoring, every 12-hours until samples maintained constant weights for up to 72-hours. The dry samples were then pulverized using mortar and pestle cleaned thoroughly with methanol before introducing each sample. At every stage of handling of samples, disinfected hand gloves were worn.

\subsection{Preparation of Extracts}

To prepare extracts of the variously dried tomato matter, $10 \mathrm{~g}$ of the finely pulverized materialwas added to a 50 $\mathrm{ml}$ conical flask and made up to mark with distilled water. This was heated on water bath for $2 \mathrm{hrs}$ at $37^{\circ} \mathrm{C}$ under vortex. The content was then filtered with Whatman filter paper\#1. The filtrates collected as extracts stock were used for antioxidant and total ascorbic acid content experimentations. 


\subsection{Antioxidant Activity}

Methods described by [8] [9] were used with slight modifications. A stock solution of $500 \mathrm{ppm}$ of Ascorbic acid in methanol was prepared and used as standard antioxidant for antioxidant (antiradical) activity. From thestock solutionof ascorbic acid, triplicates of $5 \mathrm{ml}$ solutioneach of $[10,20, \ldots 80] \mathrm{ppm}$ concentrations wereprepared in separate test tubes by using the formula ofserial dilution $\mathrm{C}_{1} \mathrm{~V}_{1}=\mathrm{C}_{2} \mathrm{~V}_{2}$. Another triplicate set where methanol was used with no ascorbic acid or extract, served as the control. Also, $5 \mathrm{ml}$ of each of the tomato extracts was pipetted in triplicates into separate test tubes. To all the test tubes, $1 \mathrm{ml}$ ofstable 2,2-diphenyl-2-picrylhydrazyl (DPPH) was added, followed by incubation for 30 minutes at roomtemperature in a dark cupboard. Absorbance was then read using a UV-Visible spectrophotometer at $517 \mathrm{~nm}$. The difference in absorbance between the test solution and the control (DPPH in methanol) was calculated and expressed aspercent scavenging or percent inhibition of DPPH radical. The antiradical activity (percent inhibition of DPPH radical) was calculated byusing the equation; Percent inhibition of $\mathrm{DPPH}=(A c-A s) / A c * 100$. [where: $A c=$ absorbance of the control, and $A s=$ absorbance of the test solution].

\subsection{Lycopene Determination}

Lycopene in the tomato samples was extracted using hexane:ethanol:acetone $(2: 1: 1)(\mathrm{v} / \mathrm{v})$ mixture following the method of Liana et al. [10], with some slight modifications.

Powdered sample $(0.001 \mathrm{~g})$ was dissolved in $1 \mathrm{ml}$ of distilled water and vortexed in water bath at $30^{\circ} \mathrm{C}$ for $1 \mathrm{hr}$. Then, $8.0 \mathrm{ml}$ of hexane, ethanol and acetone (ratio 2:1:1) was added, capped and vortexed again, followed by incubation in a dark cupboard for 60 minutes. One (1) ml of distilled water was added to each sample and vortexed once more then allowed to stand and separation into phases. Care was taken to ensure that bubbles formed had fully disappeared. The cuvette was rinsed with the upper layer of one of the blank samples before using more fresh blank samples to zero the spectrophotometer at $503 \mathrm{~nm}$. Absorbance of the upper layers of the lycopene samples were read at same wavelength of $503 \mathrm{~nm}$. Lycopene levels of the extracts were then calculated using:

$$
\text { Lycopene }(\mathrm{mg} / \mathrm{kg} \text { fresh wt. })=\left(\mathrm{A}_{503} \times 537 \times 8 \times 0.55\right) /(0.10 \times 172) \text { or, }=\mathrm{A}_{503} \times 137.4 \text {. }
$$

[where $537 \mathrm{~g} / \mathrm{mole}$ is the molecular weight of lycopene, $8 \mathrm{ml}$ is the volume of mixed solvent, 0.55 is the volume ratio of the upper layer to the mixed solvents, $0.10 \mathrm{~g}$ is the weight oftomato added, and $172 \mathrm{mM}^{-1}$ is the extinction coefficient for lycopene in hexane].

\subsection{Ascorbic Acid Determination}

This was determined by the modified Pearson's method [11]. Standard ascorbic used in the DPPH solution of methonolic DPPH calibration plot (Antioxidant activity) (above) was used, and the Ascorbic content was calculated as:

$$
\text { Mg Ascorbic acid per } 100 \mathrm{~g} \text { of sample }=100 *(V * T) / \mathrm{W} \text {. }
$$

[where: $V=\mathrm{ml}$ dye used for titration of aliquot of diluted sample, $T=$ Ascorbic acid equivalent of dye solution expressed as $\mathrm{mg} / \mathrm{ml}$ of dye, $W=$ gram of sample aliquot that will titrated]. Values were converted and presented in $\mu \mathrm{g} / \mathrm{ml}$.

\subsection{Microbiological Analysis of Powdered Tomato Samples}

Microbial population of samples particularly bacterial, fungal and yeast load, standard procedures of serial dilution and plate count as described by Adegoke [12], and Hasanuzzaman et al. [13], was used with slight modifications as most suitable to our laboratory conditions. All media and equipment were sterilized in the autoclave at $121^{\circ} \mathrm{C}$, pressure of $15 \mathrm{psi}$ for 20 minutes.Then, ten (10) grams of each sample was aseptically weighted into a $25 \mathrm{ml}$ test tube and distilled water added to the $10 \mathrm{ml}$ mark and vortexed vigorously. Standard platecount was estimated by decimal dilution technique followed by the pour plate method and spread plate method for yeast and mould.

In the pour plate method, $0.1 \mathrm{ml}$ of samples were pipetted onto sterilized Petri plates. Sterilized agar medium was cooled to about $45^{\circ} \mathrm{C}$ and was poured on the plates. The media wasmixed well by a gentle swirling motion. 
The Petri plates were then allowed to solidify then incubatedat room temperature for 48 hours. For spread plate method, $15 \mathrm{ml}$ of pre-autoclaved mediawas poured in a sterilized petri plate and kept under room temperature until the agar became solid. In potatodextrose agar plate, $0.2 \mathrm{ml}$ of the sample was dropped and the sample was spread on the agar plate withthe help of sterilized glass rod. Yeast and mould counts were determined by this method. The plate was then incubated at the $37^{\circ} \mathrm{C}$ temperature for 48 hours. All steps of this media preparation were doneunder laminar airflow.

\subsection{Statistical Analysis/Data Analysis}

Where applicable, data were expressed as mean \pm SD. Significance of difference were evaluated by ANOVA and Duncan Multiple Range Test.

\section{Results and Discussions}

Table 1 show that Rukuta and Dan-Aka species had lower antioxidant activities of $68.58 \% \pm 0.97 \%$ and $70.52 \% \pm$ $1.20 \%$ for oven dried, compared to UTC $(80.77 \% \pm 1.11 \%)$ and the market sample $(79.62 \% \pm 1.10 \%)(p>0.05)$ even though they underwent drying by the solar device while the market sample was sun dried. The UTC specie maintained significantly higher $(\mathrm{p}<0.05)$ antioxidant activities irrespective of the drying method while in Dan-Aka showed consistently lower antioxidant activities in all the drying methods used. Rukuta showed significantly higher antioxidant value under the solar drying method $(\mathrm{p}<0.05)$.

Also, in Table 1, solar dried UTC sample had the highest Ascorbic acid concentration of $164.74 \pm 2.05 \mu \mathrm{g} / \mathrm{ml}$, followed by Rukuta and Dan Aka under oven dried method with Ascorbic acid concentrations of $100.15 \pm 1.03$ $\mu \mathrm{g} / \mathrm{ml}$ and $85.33 \pm 1.78 \mu \mathrm{g} / \mathrm{ml}$ respectively $(\mathrm{p}<0.05$ ). Sun-dried samples had the lowest Ascorbic Acid concentration of $17.78 \pm 1.78 \mu \mathrm{g} / \mathrm{ml}$ for UTC, $28.44 \pm 1.78 \mu \mathrm{g} / \mathrm{ml}$ for Rukuta and $23.70 \pm 1.03 \mu \mathrm{g} / \mathrm{ml}$ for Dan-Aka (p > 0.05). The lycopene contents of the different species of tomato in Table 1 showed that solar dried, oven dried, sun-dried and even the market samples were not drastically different from one another. This implies that lycopene contents may not have been negatively affected by the various drying procedures considered in this experiment.

Total microbial count: As observed in Table 2, the method of drying of the tomato samples indeed affected the microbial loads. Generally, powders obtained by ovendrying presented comparatively lower bacterial population as in the solar drying except in the Dan-Aka tomato sample where there was an exorbitantly higher microbial load in the oven dried than the solar dried. In all cases however, the sun-dried samples presented the highest microbial population. The trend was further affirmed by the Market Sample (MktS) where there were too numerous to count (TNTC). Plate C (Market Sample) depicted it with visual clarity.

Yeast and mould count: Similar to the observations for bacterial load, both oven and solar drying methods presented lower counts than in the sun-dried samples (Table 2). However, comparably, Rukuta and Dan-Aka

Table 1. Percentage antiradical, total lycopene and ascorbic acid values of powdered tomato samples.

\begin{tabular}{ccccc}
\hline Drying medium & Tomato variety & $\begin{array}{c}\% \\
\text { Antiradical }\end{array}$ & $\begin{array}{c}\text { Lycopene content } \\
(\mathrm{mg} / \mathrm{kg})\end{array}$ & $\begin{array}{c}\text { Ascorbic acid concentration } \\
(\mu \mathrm{g} / \mathrm{ml})\end{array}$ \\
\hline \multirow{2}{*}{ Oven } & UTC & $80.77 \pm 1.11^{\mathrm{a}}$ & $147.68^{\mathrm{a}, \mathrm{b}}$ & $47.41 \pm 5.13^{\mathrm{d}}$ \\
& Rukuta & $68.58 \pm 0.97^{\mathrm{b}}$ & $135.65^{\mathrm{a}, \mathrm{b}}$ & $100.15 \pm 1.03^{\mathrm{b}}$ \\
& Dan-Aka & $70.52 \pm 1.20^{\mathrm{b}}$ & $123.63^{\mathrm{b}}$ & $85.33 \pm 1.78^{\mathrm{b}}$ \\
Solar & UTC & $76.19 \pm 0.99^{\mathrm{a}}$ & $161.98^{\mathrm{a}}$ & $164.74 \pm 2.06^{\mathrm{a}}$ \\
& Rukuta & $75.81 \pm 0.98^{\mathrm{a}}$ & $133.94^{\mathrm{b}}$ & $59.85 \pm 1.03^{\mathrm{c}}$ \\
& Dan-Aka & $68.46 \pm 0.90^{\mathrm{b}}$ & $140.81^{\mathrm{a}, \mathrm{b}}$ & $97.01 \pm 0.21^{\mathrm{b}}$ \\
Sun-dried & UTC & $78.84 \pm 1.00^{\mathrm{a}}$ & $160.27^{\mathrm{a}}$ & $17.78 \pm 1.78^{\mathrm{e}}$ \\
& Rukuta & $70.53 \pm 0.89^{\mathrm{b}}$ & $192.32^{\mathrm{a}}$ & $28.44 \pm 1.78^{\mathrm{e}}$ \\
& Dan-Aka & $73.98 \pm 0.93^{\mathrm{b}}$ & $155.69^{\mathrm{a}}$ & $23.70 \pm 1.03^{\mathrm{e}}$ \\
\hline
\end{tabular}

Values with similar superscripts have no statistical difference $(\mathrm{p} \leq 0.05)$. 
showed "no growth" (actually, low or insignificant growth) of these fungi under oven and solar drying methods, respectively (Plate A and Plate B). In this case also, the Market Sample showed fungal growth that was too numerous to count (TNTC) (Table 2 \& Plate C).

Table 2. Total microbial load of dried and powdered tomato samples.

\begin{tabular}{cccccccccccccc}
\hline $\begin{array}{c}\text { Drying } \\
\text { medium }\end{array}$ & \multicolumn{3}{c}{ Oven } & \multicolumn{1}{c}{ Solar } & \multicolumn{3}{c}{ Sun-dried } & \multicolumn{3}{c}{ Others } \\
\hline Sample & UTC & Ruk & Dan & UTC & Ruk & Dan & UTC & Ruk & Dan & MktS & Ctrl \\
\hline $\begin{array}{c}\text { TML } \\
(\mathrm{cfu} / \mathrm{g})\end{array}$ & $1.0 \times 10^{1}$ & $1.0 \times 10^{1}$ & $7.0 \times 10^{1}$ & $1.0 \times 10^{1}$ & $2.0 \times 10^{1}$ & $3.0 \times 10^{1}$ & $6.6 \times 10^{2}$ & $6.7 \times 10^{3}$ & $7.0 \times 10^{1}$ & TNTC & Ng \\
$\begin{array}{c}\text { YnM } \\
(\mathrm{cfu} / \mathrm{g})\end{array}$ & $1.0 \times 10^{1}$ & $\mathrm{Ng}$ & $3.0 \times 10^{1}$ & $1.0 \times 10^{1}$ & $2.0 \times 10^{1}$ & $\mathrm{Ng}$ & $6.0 \times 10^{1}$ & $8.0 \times 10^{1}$ & $2.0 \times 10^{1}$ & $\mathrm{TNTC}$ & $\mathrm{Ng}$ \\
$\mathrm{TC}$ & $\mathrm{Ng}$ & $\mathrm{Ng}$ & $\mathrm{Ng}$ & $\mathrm{Ng}$ & $\mathrm{Ng}$ & $\mathrm{Ng}$ & $\mathrm{Ng}$ & $\mathrm{Ng}$ & $\mathrm{Ng}$ & $\mathrm{TNTC}$ & $\mathrm{Ng}$ \\
\hline
\end{tabular}

TC = Total Coliforms; TML = Total microbial load; YnM = Yeast and Mould; $\mathrm{Ng}=$ No growth (implying low or insignificant growth); MktS = Market sample; Ruk = Rukuta; Dan = Dan-Aka; Ctrl = Control; TNTC = Too numerous to count.

\section{Oven dried}

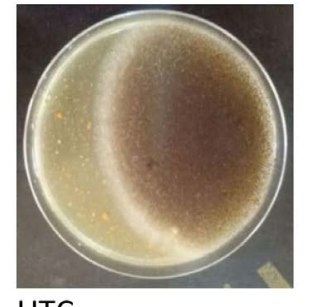

UTC

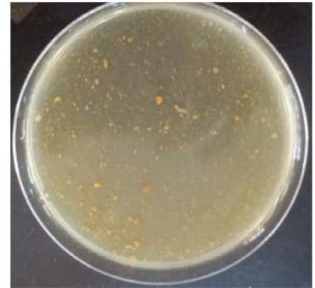

Rukuta

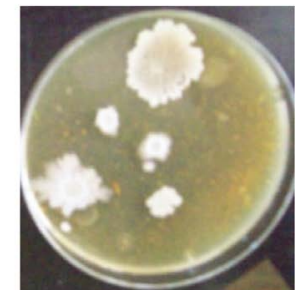

Dan-Aka

Plates A. Presence of growth in UTC and Dan-Aka but absence in Rukuta oven dried samples.

\section{Solar dried}

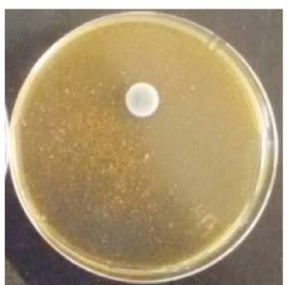

UTC

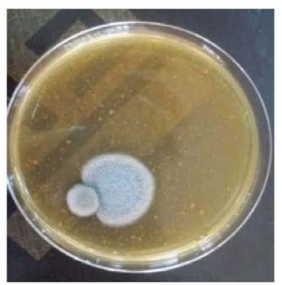

Rukuta

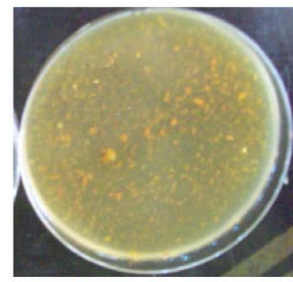

Dan-Aka

Plates B. Presence of growth in UTC and Rukuta but absence in Dan-Aka (solar dried samples).

\section{Sun dried}

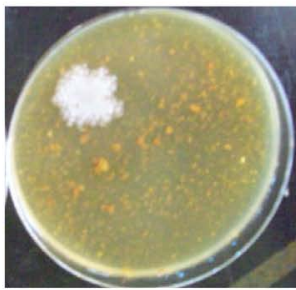

UTC

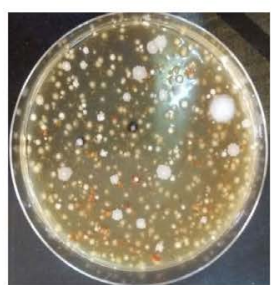

Rukuta

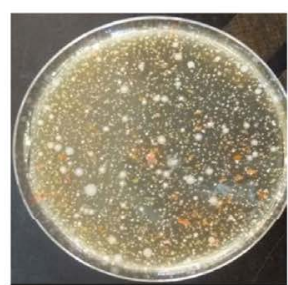

Dan-Aka

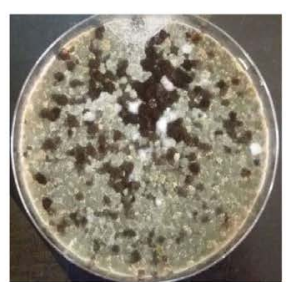

Market sample

Plates C. Presence of growth in all samples (sun dried). 


\section{Coliform presence}

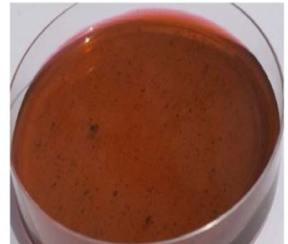

Representative

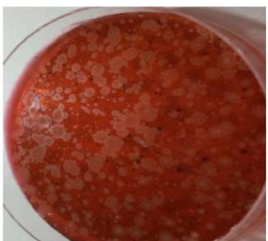

Market Sample

Plates D. Presence of coliform growth in the Market sample but absence in all sun dried samples (represented).

Coliforms: All the samples dried via the various methods showed absence of coliforms whereas, the Market Sample were too numerous to count (TNTC) (Plate D).

It was observed that, except in the Market Sample, the obtained values were within the premises of values reported by Akpan et al. [14], where yeast and mold counts were between 10.0 and $24.6 \mathrm{cfu} / \mathrm{g}$.

The total bacterial count of samples other than the Market samples in these experiments were within the accepted range byInternational Commission on Microbiological Specification for Foods, ICMSF [15], where values of $<10^{5}$ for bacteria and $10^{3}-10^{4}$ for fungi are stipulated. Drying of the tomato samples in oven and solar dryer and storing them in tightly sealed containers must have been the reasons for the low microbial loads recorded.

It has been previously found that aerobic plate counts of dry tomato sold in Nigerian markets ranged from 11.00 to $27.15 \mathrm{cfu} / \mathrm{g}$, staphylococci ranged between 17.98 and $34.13 \mathrm{cfu} / \mathrm{g}$, coliform count ranged between 10.0 and 37.86cfu/g and yeast and mould counts ranged between 10.0 and $24.67 \mathrm{cfu} / \mathrm{g}$ [14]. These reported high microbial loads were attributed to poor handling, unhygienic environment and generally unwholesome processing conditions of dry tomatoes. This includes farmers and traders who are involved in tomato processing and trading in Dutsin-ma and its environs.

In our experiment, samples were processed by simulating the local procedures as closely as possible except that hand-gloves and other necessary precautions were observed in order to obliterate cross-contamination. Besides, samples were thoroughly washed before drying, which is a huge diversion from what obtains at the local levels where no washing is usually done. As such, our procedures were presumably tidier.

Considering the fact that the oven and solar drying methods reduced the exposure of the tomato samples to high impacts of environmental rubbishes, their use in drying of tomato is reasonable. More so, in our experiment, it took shorter time specifically between 3 - 5 days to get them completely dried to enhance pulverization to powder, compared to the sun-drying method that took up to 7 days over the same dry season period. But solar drying would be of greater advantage because of the generally high evapo-transpiration throughout the year [16] and high temperatures of up to $35^{\circ} \mathrm{C}$ [17], as a result of the abundant solar radiation received in Dutsin-Ma town. It is free, while the oven-drying requires electricity which is mostly not available in the area. Besides, the huge cost of electricity to power the oven dryer, is a major disincentive to the farmers.

\section{Conclusion}

The drying of tomato and pulverization to powders has shown the retention of most of the useful chemical constituents. The Antioxidant properties and total lycopene contents were largely retained in all the samples dried with the three different methods. Ascorbic acid concentration was highly diminished among all the samples dried under the sun. Sun-drying also showed high impacts of microbial organisms. This experiment has emphasized the advantages derivable from drying tomato by methods other than direct or open sun-drying. Of particular note is the application of solar drying of tomatoes as it holds huge benefit to improving the quality of its products and by extension, the quality of lives of farmers and people living in Dutsin-Ma and its environs.

\section{Acknowledgements}

We acknowledge and appreciate the sponsorship of this research work by TETFUND and enabling environment provided by FUDMA management. 


\section{References}

[1] Famurewa, J.A.V. and Raji, A.O. (2011) Physicochemical Characteristics of Osmotically Dehydrated Tomato (Lycopersicon esculentum) under Different Common Drying Methods. International Journal of Biological and Chemical Sciences, 5, 1304-1309.

[2] Owusu, J., Ma, H., Wang, Z. and Amissah, A. (2012) Effect of Drying Methods on Physicochemical Properties of Pretreated Tomato (Lycopersiconesculentum mill.) Slices. Croatian Journal of Food Technology, Biotechnologyand Nutrition, 7, 106-111.

[3] Jayathunge, K.G.L.R., Kapilarathne, R.A.N.S., Thilakarathne, B.M.K.S., Fernando, M.D., Palipane, K.B. and Prasanna, P.H.P. (2012) Development of a Methodology for Production of Dehydrated Tomato Powder and Study the Acceptability of the Product. Journal of Agricultural Technology, 8, 765-773.

[4] Abano, E.E., Haile, M.A., Owusu, J. and Engmann, F.N. (2013) Microwave-Vacuum Drying Effect on Drying Kinetics, Lycopene and Ascorbic Acid Content of Tomato Slices. Journal of Stored Products and Postharvest Research, 4, 1122. http://dx.doi.org/10.5897/JSPPR12.030

[5] Kim, I.S., Jin, S.K., Yang, M.R., Chu, G.M., Park, J.H., Rashid, R.H.I., Kim, J.Y. and Kang, S.N. (2013) Efficacy of Tomato Powder as Antioxidant in Cooked Pork Patties. Asian-Australasian Journal of Animal Sciences, 26, 13391346. http://dx.doi.org/10.5713/ajas.2013.13079

[6] Odhiambo, F.O. (2013) Evaluation of the Effect of Tomato Powder and Reduced Nitrite Levels on Keeping and Sensory Quality of Frankfurters. A B.Sc. Industrial Project Report, Department of Food Science and Technology, University of Nairobi, Kenya.

[7] Usha, H.R., Neena, J., Suvarna, V.C., Surendra, H.S. and Nagaraju, N. (2013). Evaluation of Storage Stability Leaf Curl Resistant Cultivars for Producing Dehydrated Tomato. Discourse Journal of Agriculture and Food Sciences, 1, $1-7$.

[8] Sanja, S.D., Sheth, N.R., Patel, N.K., Patel, D. and Patel, B. (2009) Characterization and Evaluation of Antioxidant Activityof Portulaca oleracea. International Journal of Pharmacy and Pharmaceutical Sciences, 1, 74-84.

[9] Ilahi, I., Samar, S., Khan, I. and Ahmad, I. (2013) In Vitro Antioxidant Activities of Four Medicinal Plants on the Basis of DPPH Free Radical Scavenging. Pakistan Journal of Pharmaceutical Sciences, 26, 949-952.

[10] Liana, M.A., Gogoaşă, I., Despina-Maria, B., Gergen, I., Alda, S., Moldovan, C. and Niță, L. (2009) Lycopene Content of Tomatoes and Tomato Products. Journal of Agroalimentary Processes and Technologies, 15, 540-542.

[11] Pearson, D. (1991) The Chemical Analysis of Foods. Edinburgh Churchill Livingstone, UK.

[12] Adegoke, G.O. (2004) Understanding Food Microbiology. 2nd Edition, Alleluia Ventures, 173-176.

[13] Hasanuzzaman, M., Kamruzzaman, M., Islam, M.M., Khanom, S.A.A., Rahman, M.M., Lisa, L.A. and Paul, D.K. (2014) A Study on Tomato Candy Prepared by Dehydration Technique Using Different Sugar Solutions. Food and Nutrition Sciences, 5, 1261-1271. http://dx.doi.org/10.4236/fns.2014.513137

[14] Akpan, I., Olusegun, O. and Ogunfowokan, O.A. (2004) Microbiological Quality and Nutrient Composition of Dry Tomato. Journal of Food Science and Technology, 41, 420-422.

[15] ICMSF (International Commission on Microbiological Specification for Foods) [van Schothorst, M., Secretary] (1998) Principles for the Establishment of Microbiological Food Safety Objectives and Related Control Measures. Food Control, 9, 379-384. http://dx.doi.org/10.1016/S0956-7135(98)00129-7

[16] Abaje, I.B., Sawa, B.A. and Ati, O.F. (2014) Climate Variability and Change, Impacts and Adaptation Strategies in Dutsin-Ma Local Government Area of Katsina State, Nigeria. Journal of Geography and Geology, 6, 103-112. http://dx.doi.org/10.5539/jgg.v6n2p103

[17] Batagarawa, S.M. and Lawal, A.O. (2010) Determination of Some Heavy Metals Levels in Funaria Hygrometrica in Dutsinma Town of Katsina State, Nigeria. Journal of Applied Science and Environmental Management, 14, 65-68. 